\title{
A SUGAR BEET CULTIVATOR IN THE SANDY LOAM SOIL
}

\author{
Salim R. G.*, Shetawy M. A. ** and Abd Alla T. H. ***
}

\section{ABSTRACT}

This study conducted on the constructed and performance a new sugar beet cultivator is an important production operation that assists in soil loosening weeding between rows and ridge forming. However, the operation is problematic because of risks of damaging the plants during critical growth phases. The article examines a new construction for precision cultivator guidance for inter-row tillage and presents the results of field trials of the new construction. This cultivator allowed for an increase in operating speed, which would increase the efficiency of the operation. This study concentrated on comparing between exported cultivator (model Gaspardo), Italian construction and the developed cultivator, to evaluate the new cultivator, three measurements achieved, weed erasing efficiency $\left(E_{1} \%\right)$ - weed control efficiency $\left(E_{2} \%\right)$ percentage of damaged plants ( $D p \%)$. The equipment was tested under different operating conditions, at depth of cultivating $(3,5$ and $7 \mathrm{~cm})$, tractor forward speed $(3.2,4.4$, and $5.5 \mathrm{~km} / \mathrm{h})$ and three types of shares (duck leg, shovel and modified share with protection armors). The results showed that the forward speed is $3.2 \mathrm{~km} / \mathrm{h}$; depth of cultivating was $7 \mathrm{~cm}$ and the modified type of share, respectively due to its ability to level soil loosening, weeding, and ridge forming between rows and reconsolidate the soil. The aim of this work is to study and performance a local inter row cultivator that working twice, the first at $8-12$ leaves and the other after ten days from the first one to be maximizing exploitation by Egyptian investments in new reclaimed land.

\section{INTRODUCTION}

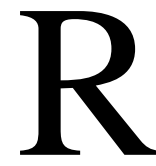
ecently, some of agricultural company planting of sugar beet in Egyptian new reclaimed land as a wide range under a complete row cultivator. Inter row cultivation, is one of the major operations,

\footnotetext{
*Agric. Eng. Res. Inst. Agric. Res Center. ** Agric. Eng. Dept., Agric. Fac. Al-Azhr Univ. ***Agric. Eng. Dept., Agric. Fac. Mans. Univ.
} 
which promotes saving soil fertility, assists with weed control and the correct use of nutrient elements in the soil. All these attributes help the crops grow and develop. Cultivation starts very soon after planting, during germination of young crops, and continues 4 to 5 months until the end of the growing season. Inter row cultivation is one of the most problematic and costly operations for growers in Uzbekistan because it still requires using hand labor. Just for hand weeding growers spend up to $40 \%$ of the total cost for cotton production (Mirakhmedov, et.al, 1989). Abdel-Latif (1992) showed that weeds compete with the crop for nutrients, water and sunlight. They re-infest the field when allowed to produce seeds; furthermore, such weeds may interfere with harvesting equipment and cause a decrease in yield and harvesting efficiency. Hanna et al., (2000) and Thacker et al, (2002) showed that, mechanical cultivators are major proven units for inter row cultivation in sugar beet, corn, cotton and soybean and have been successfully used in the United States, Canada and Europe. They can be effective for weed control when economical and environmental considerations are taken into account. During inter row cultivation a unit, which consists of a tractor and cultivator, moves between the rows of the crop for soil loosening, weeding, fertilizing, and ridge forming. Unfortunately, these operations require very accurate driving to prevent plant damage leading to crop loss. The operating parts of the cultivator, depending on type and working depth, must maintain certain clearances from the crop line. Therefore, an uncultivated (protected) zone/strip centered on the plant row remains. Amonov, et al (2006) showed that, the proposed cultivator utilizes light torsion pivots with gauging beams and guiding slits to allow a reduction of the protected zone surrounding the plant by 2 to $2.5 \mathrm{~cm}$ and improves the soil surface condition (soil crumbling ability). Herbicide use and hand labor can be significantly reduced, which should lead to an increase in profit.

\section{MATERIALS AND METHODS}

This study was carried out to investigate the performance and operating parameters of a developed manufactured cultivator during sugar beet cultivation in the sandy loam soil, and choosing between performance of 
three different shapes of shares used with this cultivator, comparing with exported cultivator.

\section{The developed cultivator :-}

The developed cultivator was constructed and fabricated at the local workshop. During the construction of the cultivator the following points have been taken into consideration:

1- All parts are made of local materials, as show in table (1).

2- The developed cultivator should have simple mechanisms and shape.

3- Using the developed cultivator caused minimum damage of sugar beet plants and highest weed erasing.

4- The developed cultivator suitable for working in a sandy loam soil with inter row sugar beet cultivation.

5- Minimum cost to an increase in profit.

Table (1) : Materials that used in construction of developed interrow cultivator

\begin{tabular}{|c|l||l|}
\hline No. & \multicolumn{1}{|c|}{ Item } & \multicolumn{1}{|c|}{ specifications } \\
\hline \hline 1 & Main beam (cultivator frame) & $0.10 \times 0.10 \times 9 \mathrm{~m}$. \\
\hline 2 & Spring beam & $0.6 \times 0.2 \times 1.5 \mathrm{~m}$. \\
\hline 3 & Plate & $24 \times 0.6 \mathrm{~m}$. \\
\hline 4 & Pipe & $1 \times 0.2 \mathrm{~m}$. \\
\hline 5 & Clump device beam & $0.04 \times 0.04 \times 2 \mathrm{~m}$. \\
\hline 6 & Hitch frame beam & $0.05 \times 0.05 \times 3 \mathrm{~m}$. \\
\hline 7 & Stud & $0.02 \times 3 \mathrm{~m}$. \\
\hline 8 & Screws 17 & $2 \mathrm{~kg}$. \\
\hline 9 & Screws 24 & $3 \mathrm{~kg}$. \\
\hline \hline 10 & Sleeve & $0.03 \times 0.01 \mathrm{~m}$. \\
\hline
\end{tabular}

The developed cultivator costs 15000 E.P and manufactured to suitable cultivation of 6 rows and consists of adjusting depth wheel to enable controlling cultivation depth. A modified share with wings supply with protection armors was manufactured and the compared study between its 
performance with duck leg share and shovel share was carried out. A 120 $\mathrm{hp}$ tractor model Fiat as source of power with this cultivator in the field The main component of the local cultivator and its dimensions demonstrated in fig.s (1 and 2) and fig. (3).
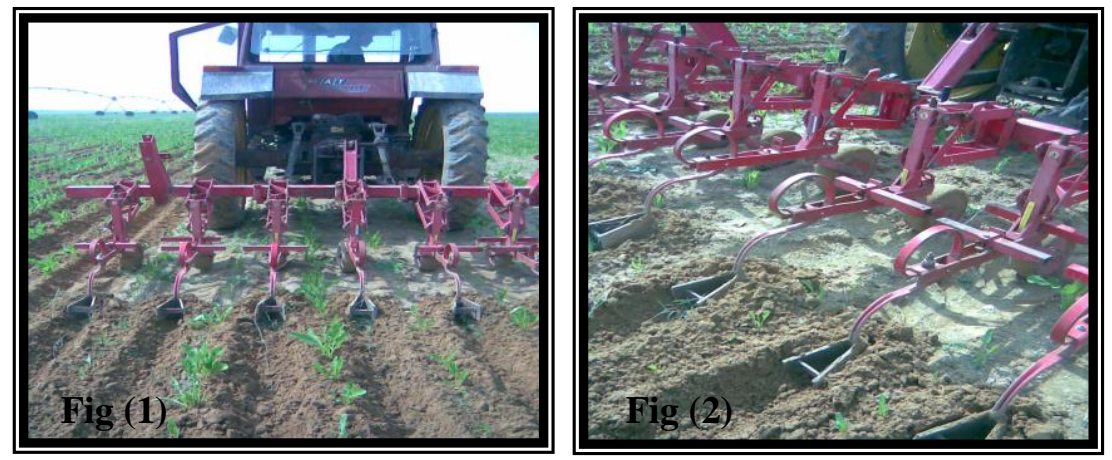

Fig.s (1 and 2): The local cultivator while working in the field

Cultivator frame.

(2) Clump device.

(3) The fuse of depth control.

(4) The shin.

(5) Protection armor

(6) Developed share.

(7) Adjusting depth wheel.

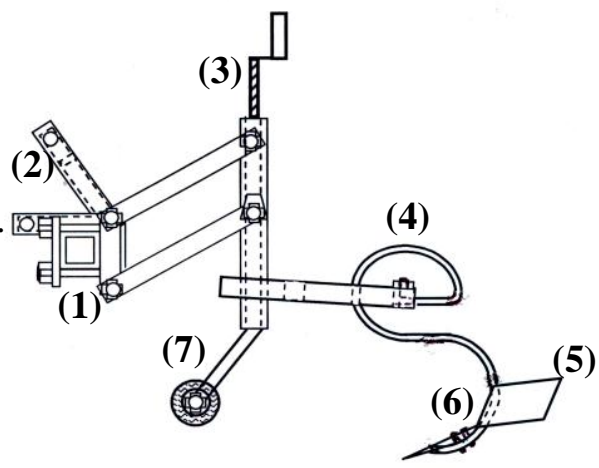

Fig. (3): A side view schematic diagram for developed cultivator with modified share.

\section{The export cultivator}

To determine the influence of using developed cultivator, its important to compare its performance with another exported cultivator usable in sugar beet cultivation, in this study the exported cultivator model Gaspardo Italy made 2007 costing 65.000 E.P 6 rows with duck leg share and consists of adjusting depth wheel as shown in fig. (4). A $120 \mathrm{hp}$ Fiat tractor with this cultivator as a source of power in the field. As shown in fig. (5). 


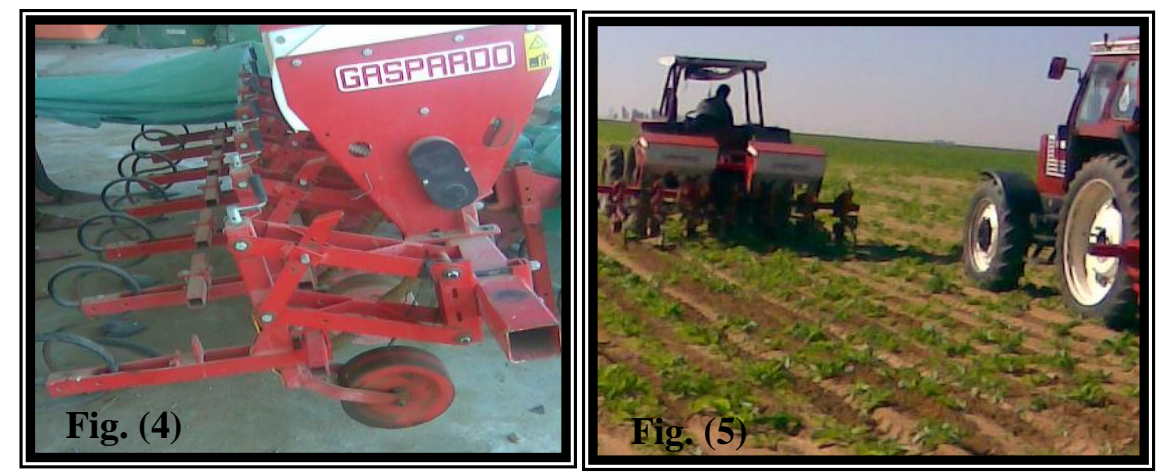

Fig. (4 and 5) : The export cultivator model Gaspardo.

The actual field experiments were conducted at the Salihea sector- AlSharkea Governorate. The field experiments were carried out in a sandy loam soil during sugar beet cultivation after planting sugar beet in winter season of 2010-2011. The chemical and mechanical properties of the experimental soil are summarized in table (2).

Table (2): The chemical and mechanical analysis of the experimental field soil.

\begin{tabular}{|c|c|c|c|c|c|c|c|}
\hline \multicolumn{4}{|c|}{ Particle size distribution \% } & \multirow{2}{*}{$\begin{array}{c}\text { Soil } \\
\text { texture }\end{array}$} & \multirow[b]{2}{*}{ PH } & \multirow{2}{*}{$\begin{array}{c}\mathrm{CaCo}_{3} \\
(\%)\end{array}$} & \multirow{2}{*}{$\begin{array}{c}\text { Soil bulk } \\
\text { density } \\
\text { gm/cm }\end{array}$} \\
\hline Clay & Silt & $\begin{array}{l}\text { Fine } \\
\text { sand }\end{array}$ & $\begin{array}{c}\text { Coarse } \\
\text { sand } \\
\end{array}$ & & & & \\
\hline 6.4 & 3.8 & 16.1 & 71.52 & $\begin{array}{l}\text { sandy } \\
\text { loam }\end{array}$ & 8.1 & 2.18 & 1.4 \\
\hline
\end{tabular}

\section{Scope of factors:-}

The main factors used in field experiments were as follows:-

1-Two cultivating machines (developed cultivator with three different shares \& Export cultivator model Gaspardo with duck leg share).

2-Three tractor forward Speeds: $\left(\mathbf{F s}_{\mathbf{1}}=3.2\right) \&\left(\mathbf{F s}_{\mathbf{2}}=4.4\right) \&\left(\mathbf{F s}_{\mathbf{3}}=\right.$ $5.5) \mathrm{km} / \mathrm{h}$.

3- Three levels of working depth of cultivator share $\left(\mathbf{d}_{1}=3\right) \&\left(\mathbf{d}_{2}=\right.$ 5) $\&\left(\mathbf{d}_{\mathbf{3}}=7\right) \mathrm{cm}$.

4- Three types of shares used in developed cultivator (Duck leg share $\boldsymbol{\&}$ shovel share $\boldsymbol{\&}$ modified share with wings) 


\section{Experimental measurements}

There were three measurements were calculated as follows:

1- Weed erasing efficiency $\left(\mathbf{E}_{\mathbf{1}} \boldsymbol{\%}\right)$ : The weed erasing efficiency intended is the number of weeds that already removed in the $20 \mathrm{~m}$. of the row, counted directly after cultivation and estimating at different treatments under study by the following equation.

where:

$$
E_{1}=\left(1-\frac{R_{1}}{R}\right) \times 100
$$

$\mathbf{R}_{\mathbf{1}}=$ Number of stay weeds directly after cultivation.

$\mathbf{R}=$ Total number of weeds.

2- Weed control efficiency $\left(\mathbf{E}_{2} \boldsymbol{\%}\right)$ : The weed control efficiency intended is the number of weeds that already removed in the $20 \mathrm{~m}$. of the row, counted after 10 days from cultivation and irrigation and estimating at different treatments under study by the following equation.

where:

$$
E_{2}=\left(1-\frac{R_{2}}{R}\right) \times 100
$$

$\mathbf{R}_{\mathbf{2}}=$ Number of weeds that stay after 10 days from cultivation and irrigation.

3- Percentage of damaged plants (Dp \%) : The percentage of damaged sugar beet plants intended the number of plants that are damaged from passing the cultivator, estimated at different treatments under study by the following equation.

$$
D p=\left(1-\frac{N_{d}}{N_{p}}\right) \times 100
$$

where:

$\mathbf{N}_{\mathbf{d}}=$ Number of undamaged plants.

$\mathbf{N}_{\mathbf{p}}=$ The total number of growing plants before passing of cultivator.

\section{RESULTS AND DISCUSSION}

\section{1- Weed erasing efficiency $\left(\mathrm{E}_{\mathbf{1}} \%\right)$ :}

Fig.s (6a throw 6c) show that, the highest value of weed erasing efficiency $93 \%$ obtained at modified share in developed cultivator at highest cultivation depth $\left(\mathrm{d}_{3}=7 \mathrm{~cm}\right)$ and the lowest forward speed $\left(\mathrm{F}_{\mathrm{S} 1}=\right.$ $2.8 \mathrm{~km} / \mathrm{h}$ ), the lowest value of weed erasing efficiency $74 \%$ obtained by 
using developed cultivator with shovel share at the lowest cultivation depth $\left(\mathrm{d}_{1}=3 \mathrm{~cm}\right)$ and the highest forward speed $\left(\mathrm{Fs}_{3}=5.5 \mathrm{~km} / \mathrm{h}\right)$, one can say that, the highest value of weed erasing efficiency mean that the highest number of weeds that already erasing with modified share, due to its wide enough to erase weeds more than another types of shares
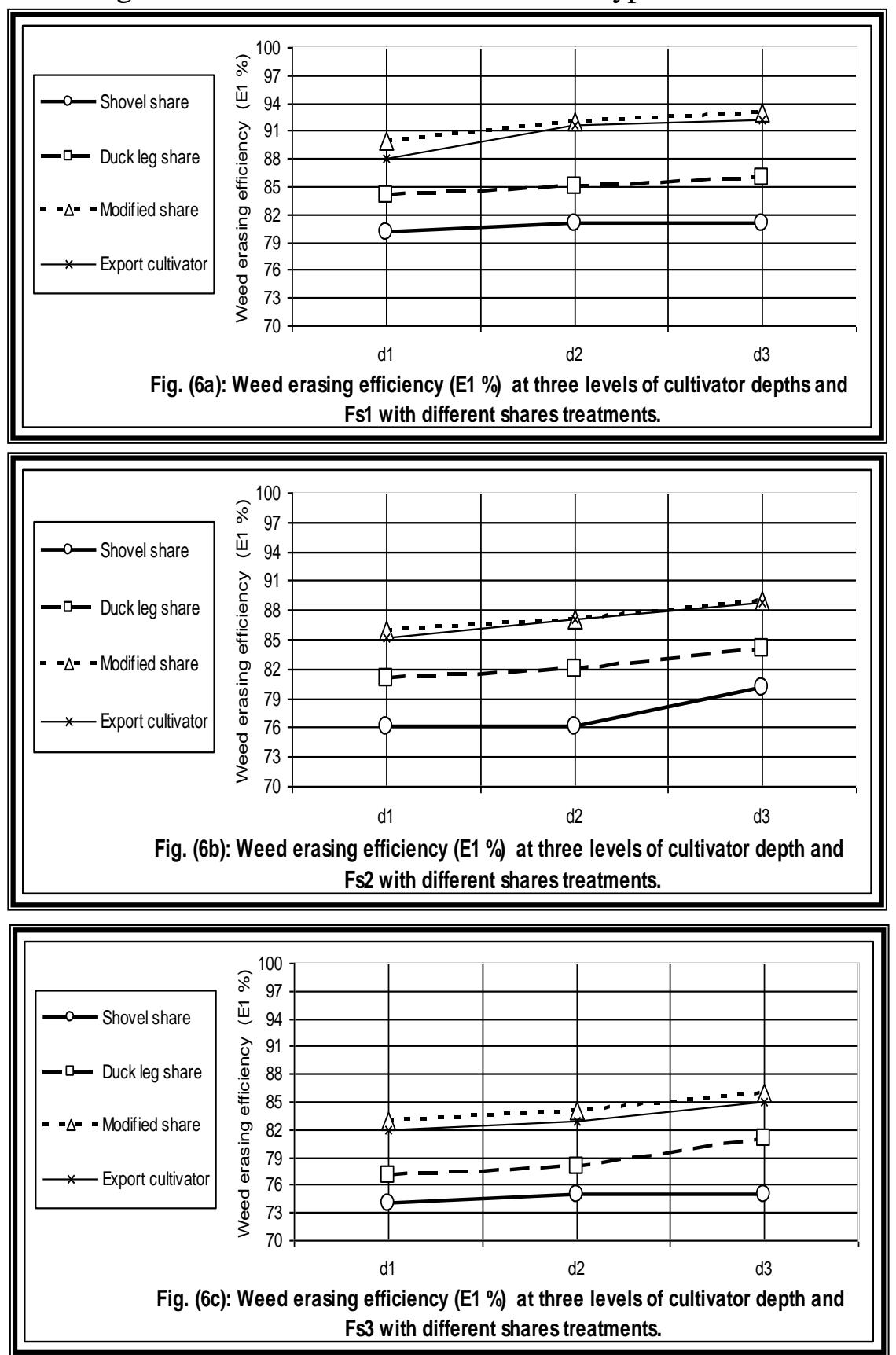


\section{2- Weed control efficiency $\left(E_{\mathbf{2}} \%\right)$ :}

Fig.s (7a throw 7c) show that, the highest value of weed control efficiency $89.8 \%$ in row after 10 days from cultivation and irrigation was obtained at modified share in developed cultivator at highest cultivation depth $\left(\mathrm{d}_{3}=7 \mathrm{~cm}\right)$ and the lowest forward speed $\left(\mathrm{F}_{\mathrm{S} 1}=2.8 \mathrm{~km} / \mathrm{h}\right)$, the lowest value of weed control efficiency $69 \%$ obtained by using developed cultivator with shovel share at the lowest cultivation depth $\left(\mathrm{d}_{1}\right.$ $=3 \mathrm{~cm})$ and the highest forward speed $\left(\mathrm{Fs}_{3}=5.5 \mathrm{~km} / \mathrm{h}\right)$ this due to, using developed cultivator with modified share erased the highest number of weeds, at maximum depth because of modified share can cut roots of weeds that led to erasing of weeds, this explain remaining the lowest number of weeds in row.

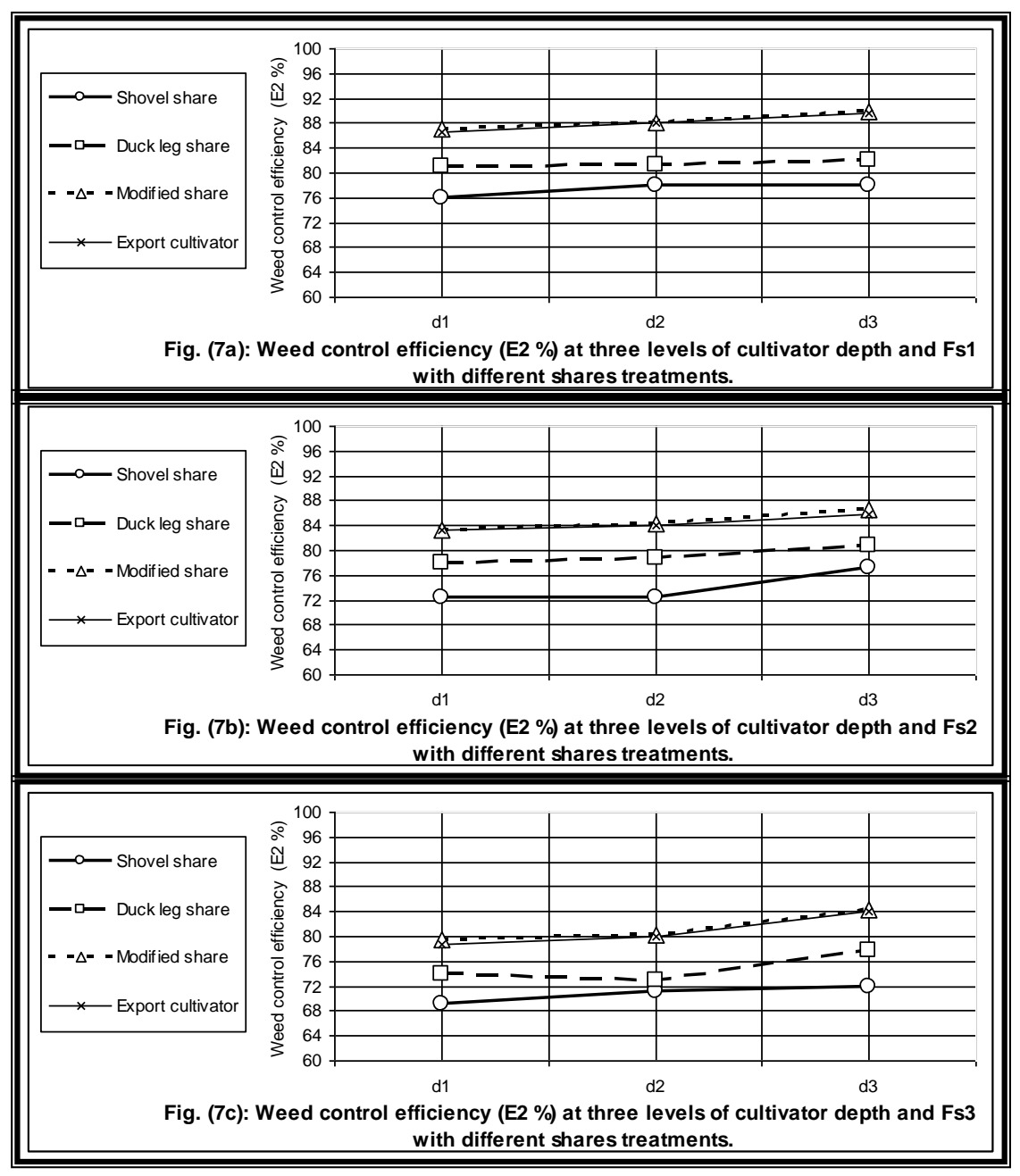




\section{3- Percentage of damaged plants (Dp \%)}

Inspection of data demonstrated in figs. (8-a through 8-c) shows that the lowest plant damage $(0 \%)$ was obtained with modified and shovel share in developed cultivator at lowest depth $\left(\mathrm{d}_{1}=3 \mathrm{~cm}\right)$ and lowest forward speed $\left(\mathrm{Fs}_{1}=2.8 \mathrm{~km} / \mathrm{h}\right)$, the highest damage plant percentage $(1.2 \%)$ was obtained with duck leg share in export and developed cultivator at highest cultivator depth $\left(\mathrm{d}_{3}=7 \mathrm{~cm}\right)$ and highest forward speed $\left(\mathrm{Fs}_{3}=5.5\right.$ $\mathrm{km} / \mathrm{h}$ ). one can notice that, the modified share with protection armors protected plants to be damaged and shovel share is width-less than other shares used in this study which have a less efficiency in removing weeds also less damage of plants in rows.

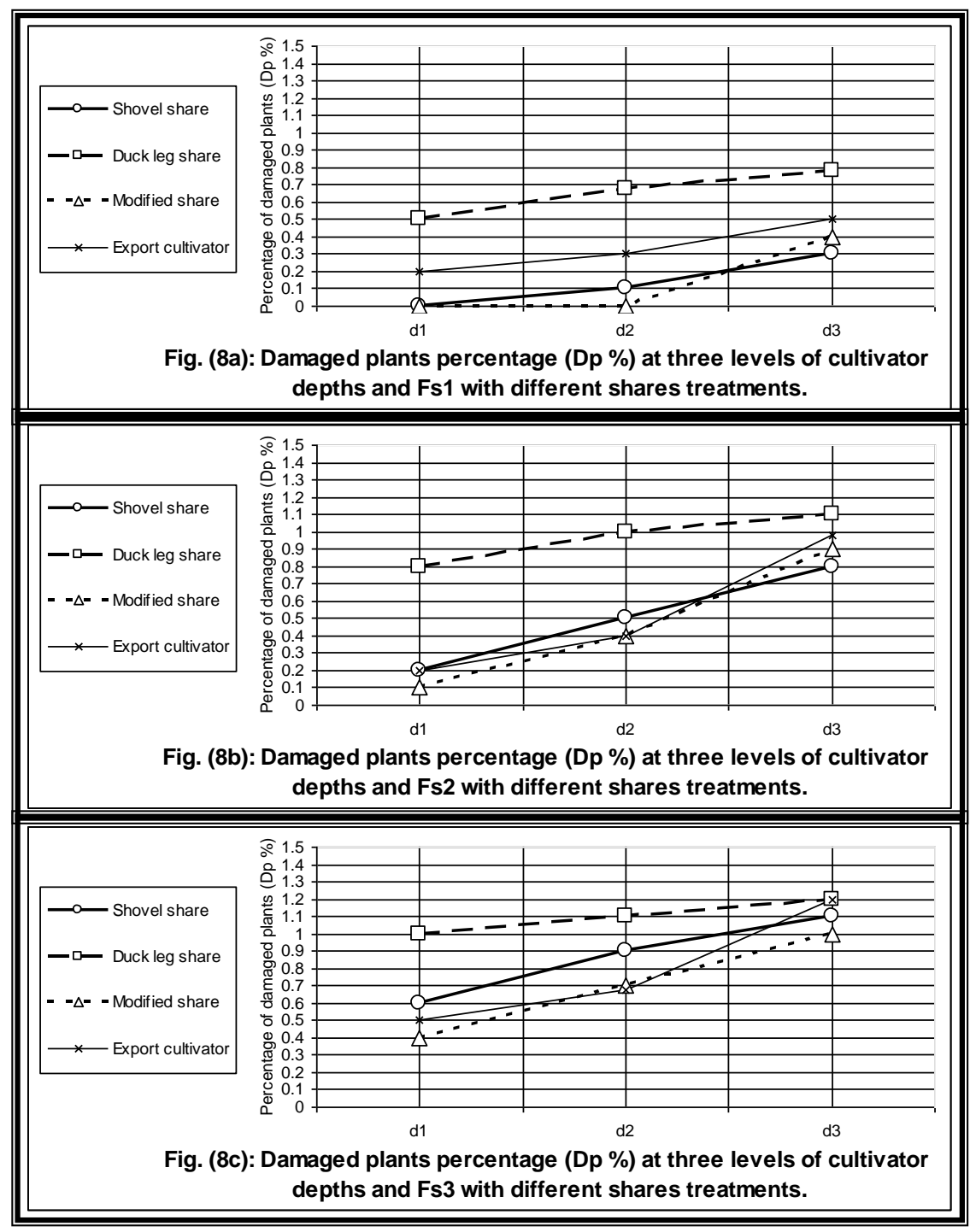




\section{REFFERENCES}

Mirakhmedov S.M., S.Kh. Yuldashev, A.S. Samutali, G.M. Rudakov, S.N. Alimukhamedov, A.A. Abdullaev, Sh.I. Ibrohimov, O.V. Lebedev, N.F. Bespalov, A.Kh. Khojiev and P.N. Besedin. (1989). Cotton-Growing Handbook, 134-141, 249-255. Tashkent, Russia: Mehnat

Abd EL-Latif, Y. Z. (1992). Evaluation of weed control in sugar-beat production. Misr. J. Agric. Eng. 9(3): 267-276.

Hanna, H. M., R. G. Hartzler, and D. C. Erbach. (2000). High-speed cultivation and banding for weed management in no-till corn.Applied Engineering in Agriculture16(4):359-365.

Amonov, M. O., Pulatov, T. S., Colvin, T. S. (2006) "Machine innovation for inter row cotton cultivation in Uzbakistan" American Society of Agricultural and Biological Engineers ISSN 0883-8542. Vol. 22(5): $665-674$.

Thacker, G. W., and W. E. Coates. (2002). How to mechanically remove weeds from the row. Available at

http://cals.arizona.edu/crops/equipment/removeweed.html

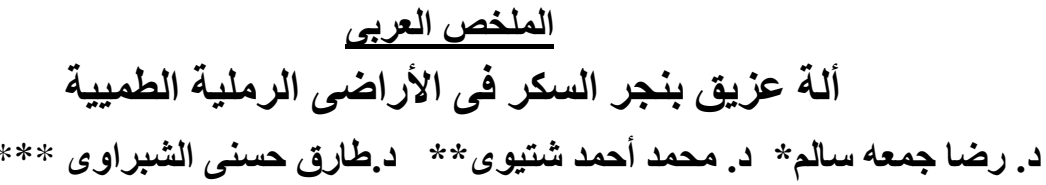

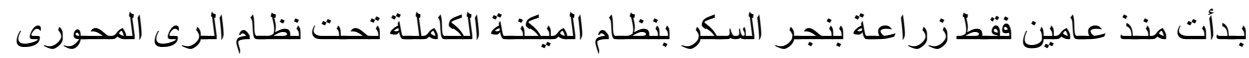

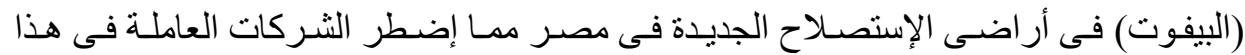

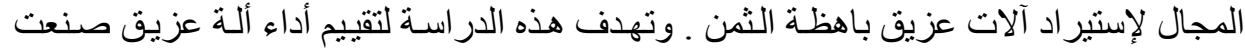

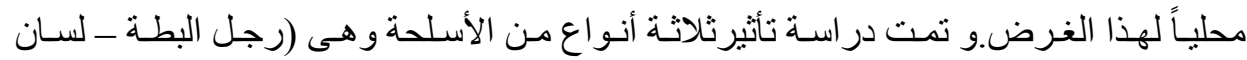

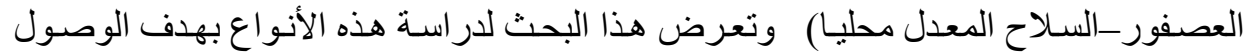

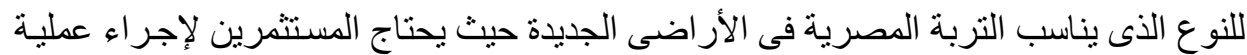

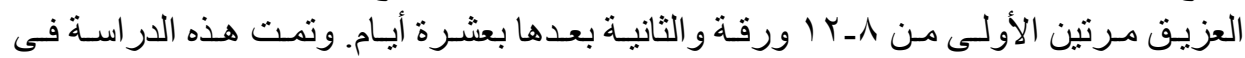

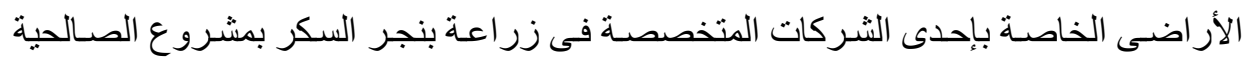

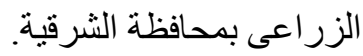

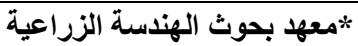

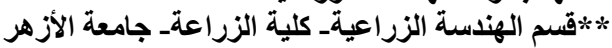

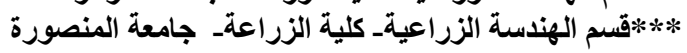




$$
\begin{aligned}
& \text { وتركزت عوامل الدراسة فيما يلى: }
\end{aligned}
$$

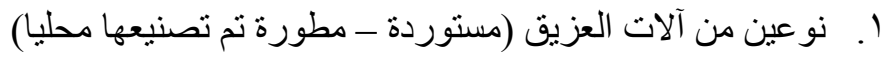

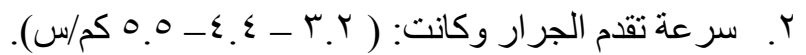

$$
\begin{aligned}
& \text { r. . نوع السلاح: (لسان العصفور -رجل البطة ـالسلاح المعدل محليا) } \\
& \text { ك. عمق العزيق: ( } \\
& \text { كما تركزت القياسات فيما يلى: }
\end{aligned}
$$

ا ا ب. كفاعة عملية التقليع.

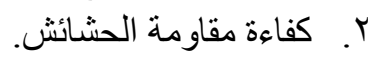

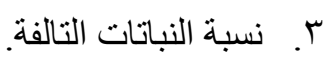

وخلصت الدراسة للتنائج التالية:

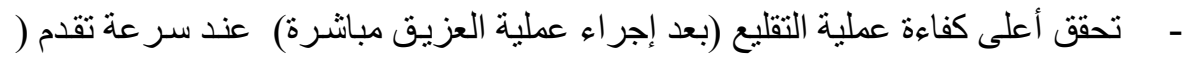

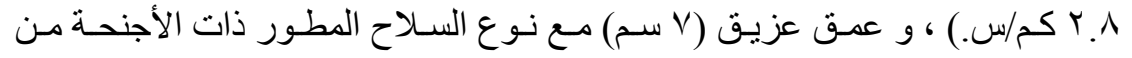
أسلحة العزيق و كانت بوه\% من عدد الحشائش التى تم إز التها بالفعل.

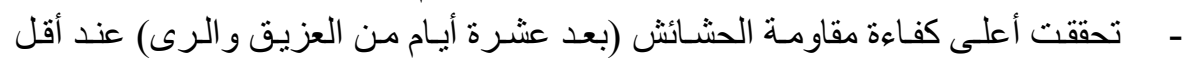

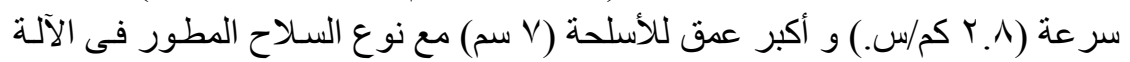

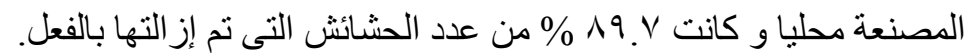

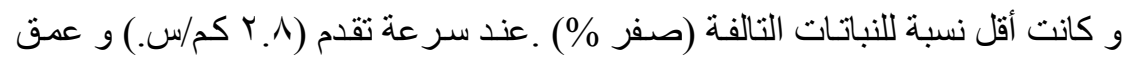

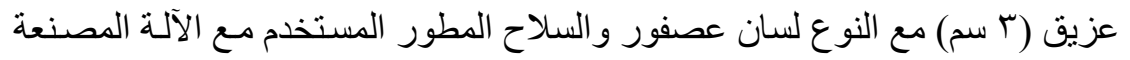
محليا. و توصى الدر اسة بإستعمال المعاملات التى حقت أعلى كفاءة مقاومة الحشائش. 